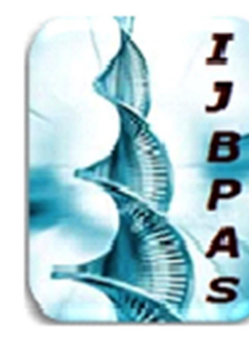

International Journal of Biology, Pharmacy and Allied Seiences (IJBPAS)

'A Bridge Betueen Caboratory med QRendo'

www.ijbpas.com

\title{
MONITORING OF COASTAL ZONE, GULF OF KACHCHH WITH REFERENCE TO LAND USE LAND COVER CHANGES USING REMOTE SENSING AND GIS
}

\section{KAJAL JOSHI ${ }^{* 1}$ AND KABIR MOHAN SETHY ${ }^{2}$}

1: Post Doctoral Fellow, Centre of Environment, Climate Change and Public Health (ECCPH), Utkal University, Bhubaneswar, Odisha, India

2: Professor, Department of Geography, Utkal University, Bhubaneswar, Odisha, India

*Corresponding Author: Kajal Joshi; E Mail: kajaljoshi101@gmail.com

Received $19^{\text {th }}$ July 2021; Revised 20 ${ }^{\text {th }}$ Aug. 2021; Accepted 29 ${ }^{\text {th }}$ Sept. 2021; Available online $1^{\text {st }}$ Nov. 2021

https://doi.org/10.31032/IJBPAS/2021/10.11.1028

\begin{abstract}
Human population and activities in the world are generally concentrated near the coast, which has modified the environment for thousands of years. Coastal development leads to modification of foreshore and loss of key habitats such as mangroves, coral, sea grasses etc. Because of this collision of impacts and uses, managing coastal zone can be a high priority for all the coastal nations. Coastal zones are more vulnerable for land use pattern change in the rapid era of urbanization and industrialization. To protect the current natural resources and to know about the causes and consequences of more utilization of water and soil resources a land use land cover (LULC) monitoring and mapping was carried out in the Gulf of Kachchh, the most hastily growing industrial hub of India. Geospatial techniques were used to monitor and evaluate the change in LULC in the Gulf of Kachchh from 1997 to 2016. LISS-III satellite images and digital change detection methods were used. The satellite images were classified using supervised classification method and expert visual interpretation. KAPPA analysis and Error matrix have been done for the accuracy assessment. Change detection among the satellite images for all the nine LULC classes was calculated. The overall classification accuracy of the image is $91.46 \%$ with Kappa statistics of 0.89 . This study shows that the major LULC change identified in agricultural land
\end{abstract}


followed by mudflats and water bodies, which are significantly decreased, while mangrove, saltpan, built up, industries and mining are increased from 1997 to 2016.

\section{Keywords: LISS III image, KAPPA analysis, Supervised classification, Change detection}

\section{INTRODUCTION}

Coastal zones are more natural creative regions and essential apparatus of the universal ecosystem [1]. These coastal zones have prosperity of different species and genetically diverse habitat and are main oxygen sources and carbon sink. Hence, these zones play an essential role in regulating global ecosystem and climate [2]. World's almost half population stays within $60 \mathrm{~km}$ of the coastal line and would increase around three quarters by 2025 [3]. The LULC pattern of each area is a result of socio economic and natural factors and their exploitation by man in time and space. In recent years, LULC change become an important component to manage natural resources and to supervise environmental changes [4]. From last few years, Gulf of Kachchh, Gujarat is having increased anthropogenic pressure because of urbanization and industrialization. Thus, there is a critical need to evaluate and monitor LULC changes to build efficient strategies for coastal zone management. Mostly coastal zones are influenced by dredging, tipping and reclamation activities [5]. Satellite images provide a synoptic view of the coastal zones [6]. The recent scientific technologies such as digital image processing and remote sensing are very helpful in periodic assessment of the LULC changes of the coastal area and appraise them to plan better management [7].

The present study shows the purpose of LULC change analysis of Gulf of Kachchh using remote sensing. LISS III satellite images were used for determination of LULC changes of study area. The images were analyzed using data image processing technique in ERDAS Imagine ${ }^{\circledR}$ and Arc GIS ${ }^{\circledR}$. Land use and land cover nomenclature is classified according to the National State Remote Sensing Agency (NRSA). Furthermore, the image analysis outcomes are confirmed through ground surveys.

\section{MATERIALS AND METHODS}

The study and research work is carried out in the coastal area of Gulf of Kachchh (within $20 \mathrm{~km}$ from the shoreline), Gujarat. Gulf of Kachchh (GoK) is the massive coastal zone in the west coastal part of India in the state of Gujarat $\left(20^{\circ} 15^{\prime}\right.$ to $23^{\circ}$ $35^{\prime} \mathrm{N}$ and $60^{\circ} 05^{\prime}$ to $70^{\circ} 22^{\prime} \mathrm{E}$ ) which is spread over $1000 \mathrm{~km}$ long coastline covering an area of $7350 \mathrm{sq} \mathrm{km}$ and a volume of $220,000 \mathrm{Mm}^{3}$. The GoK lies 
among the Saurashtra/Kathiawar peninsula in the south and the mainland of Kachchh in the north and is open to the Arabian Sea in the west [8]. The GoK has unique marine habitat like mangroves and coral reef in the southern coast and mangroves habitat at certain locations by the side of the northern coast. The GoK is very wealthy in terms of biodiversity values. The GoK supports various habitats including coral reefs, mangroves, creeks, mud flats, islands, rocky shore, sandy shore etc., which in turn provide suitable environment for wide range of flora and fauna. The gulf zone is very much affluent in diversity of marine life. The map of GoK indicating study area is shown in Figure 1.

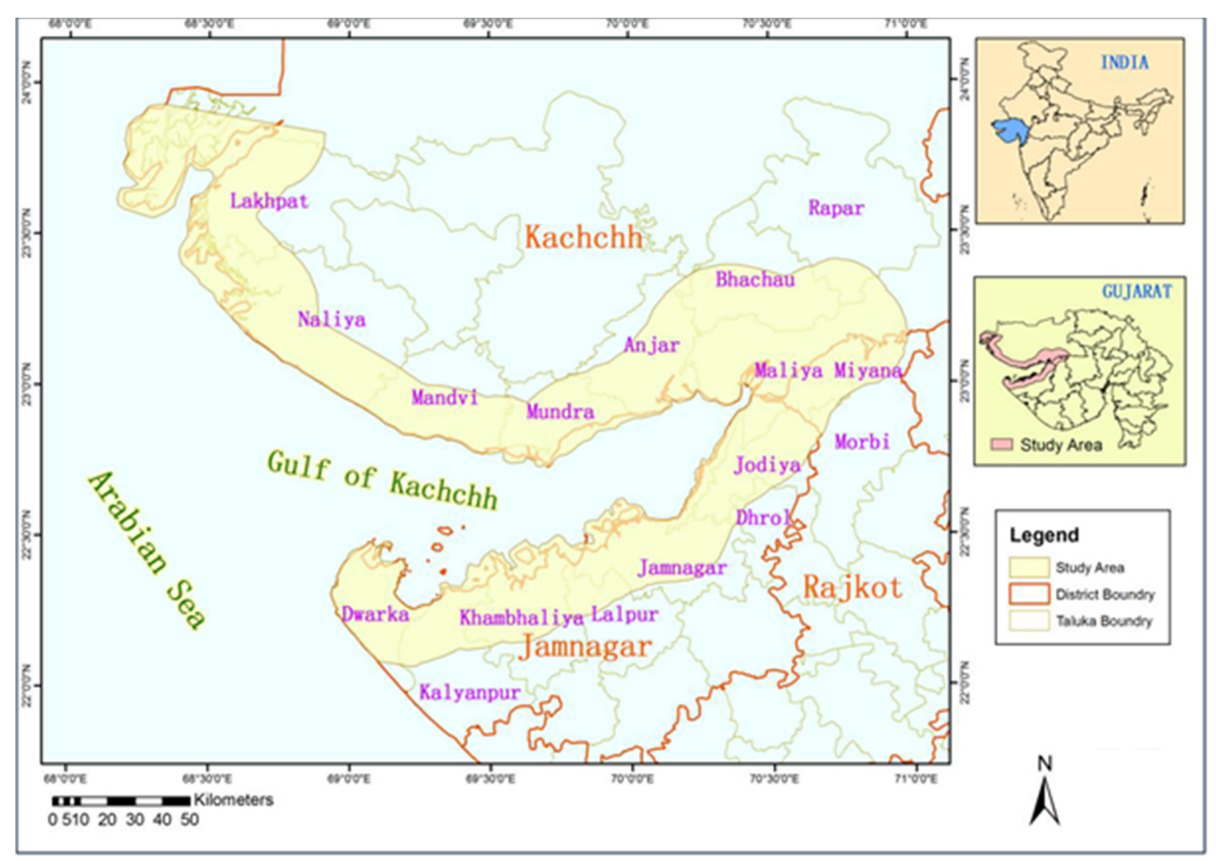

Figure 1: Map showing the study area of the present study

Scene wise Geo-referenced LISS-III satellite data for years 1997, 2002, 2007, 2012 and 2016 were acquired from the Bhaskaracharya Institute for Space Application and Geoinformatics (BISAG) and National Remote Sensing Centre (NRSC). The research involved two main steps, classification of satellite data for LULC types and the change detection analysis in the LULC types. Satellite data analysis includes registration, classification and change detection using postclassification comparison. Analysis of satellite data is done by using spatial analyst tool in Arc GIS ${ }^{\circledR}$ and $\operatorname{ERDAS}^{\circledR}$. LULC maps were prepared for multi date satellite images. Land use land cover change analysis was conceded using Arc GIS $^{\circledR}$. Ground truthing was carried out using GPS to access the accuracy of visual interpretation.

\section{Image Classification Methods}


The main objective of image classification method is to automatically classify all the pixels in the image into LULC classes to acquire valuable thematic information [9]. Multi spectral image classification is the most useful method to extract thematic information from satellite images [10]. The land use land cover maps were prepared for the LISS-III image of years 1997, 2002, 2007, 2012 and 2016. Image classification was carried out using hybrid classification method connecting both unsupervised and supervised techniques [11]. Among different classification algorithms, maximum likelihood was applied for supervised classification by taking 90 training areas for nine major LULC class categories (10 training points for each LULC class). The LULC classes include agricultural land, built up area, industries, mangrove, mining area, mudflat, saltpan, waste land and water bodies (Table 1).

Table 1: Description of Land Use Land Cover Classes

\begin{tabular}{|c|c|}
\hline Land Use/ Land Cover Class & Description \\
\hline Agricultural Land & $\begin{array}{l}\text { Areas allotted to rain fed and irrigated cultivation, including fallow plots, } \\
\text { agricultural land mixed with some bushes, trees and the scattered rural } \\
\text { settlements included within the cultivated fields. }\end{array}$ \\
\hline Built Up & $\begin{array}{l}\text { Areas that have been populated with residential, commercial, transportation and } \\
\text { facilities. Settlements, roads and tourist places }\end{array}$ \\
\hline Industries & Areas that have been allotted to industry, port and land for port activity. \\
\hline Mangrove & Trees which are adapted in saline water with high tide and low tide. \\
\hline Mining area & Areas that have been allotted for the open cast mining \\
\hline Mud Flat & Area covered with mud at coast line. \\
\hline Saltpan & Area in which salt produce by evaporation of sea water. \\
\hline Wastelands & $\begin{array}{l}\text { Mountainous or hilly areas, areas with no vegetation cover or degraded } \\
\text { agricultural lands. }\end{array}$ \\
\hline Water bodies & $\begin{array}{l}\text { Areas covered by manmade small dams, seasonal water bodies and permanent } \\
\text { water bodies (rivers, lakes and sea). }\end{array}$ \\
\hline
\end{tabular}
After [12 - 15]

Area statistics is estimated in hectors of every land use land cover category in attribute table of ERDAS Imagine as suggested by Abate (2011) (Table 2). The classified images were edited on the basis of the ground truth data collected from the field and then finally classified maps were generated with assessing classification accuracy using the tool accuracy assessment of ERDAS $^{\circledR}$ where land use land cover maps were used in raster format. By applying random points in accuracy assessment window we established accuracy report containing overall classification accuracy [16]. Image analysis operations have been carried out using GIS and finally the changes in various LULC classes are acquired using post classification comparison method. KAPPA analysis and Error matrix were done for the accuracy assessment of the classification [17]. The output was evaluated for land cover degradation and interpreted with ancillary data collected from various state government departments. The results acquired were used in order to evaluate the stress of land 
use and land cover on ecosystem for the better management of natural resources.

\section{RESULTS AND DISCUSSION}

\section{Supervised Classification of the Study}

\section{Area}

Figure 2 to 6 shows the classified images of the Gulf of Kachchh for the years 1997, 2002, 2007, 2012 and 2016 respectively. The accuracy assessment is so significant that it tells us to what extent the truth on the ground is represented on the corresponding classified image. Overall classification accuracy of the image was calculated adding the number of correctly classified pixels and dividing it using the total number of pixels. Overall classification accuracy of the image is $91.46 \%$ with Kappa statistics of 0.89 . Post classification change statistics between 1997, 2002, 2007, 2012 and 2016 gives the total amount of area covered by the different classes and the change observed. Table 2 gives the area of each LULC categories in different years in hectare. Table 3 presents the change in each LULC class every five years. Figure 7 shows the change of each LULC class from 1997 to 2016.

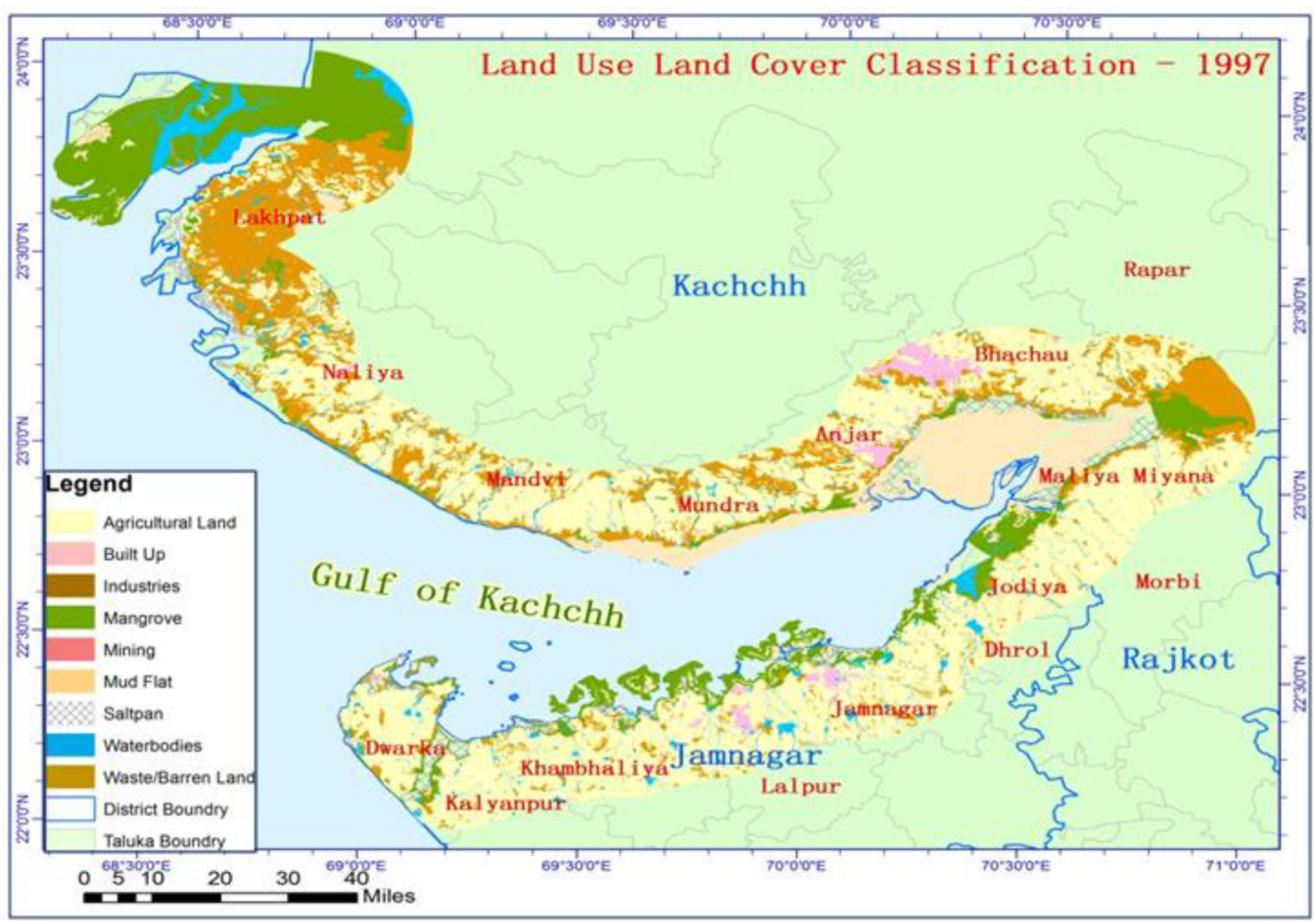

Figure 2: Classified image of the coastal area of GoK in year 1997 


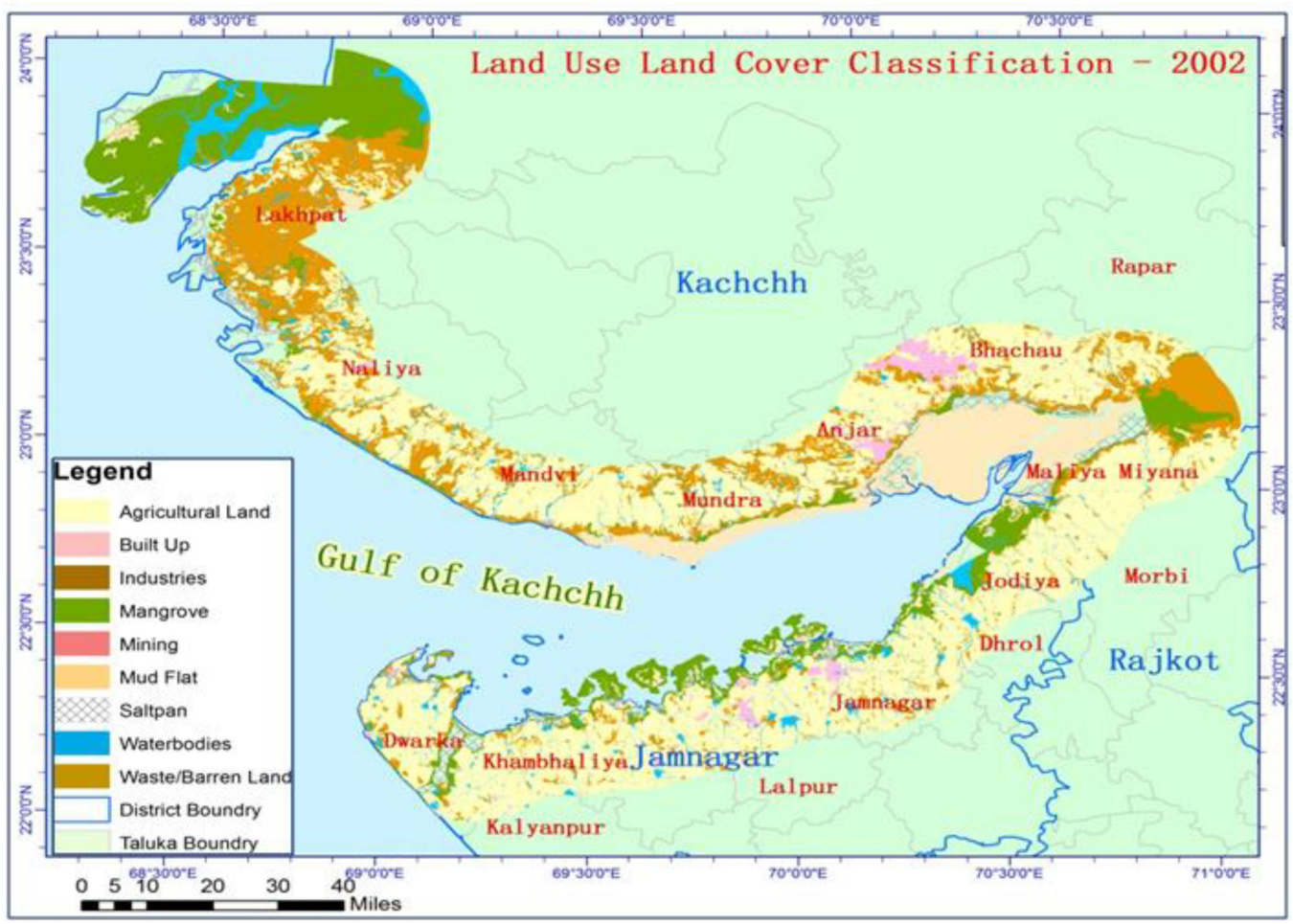

Figure 3: Classified image of the coastal area of GoK in year 2002

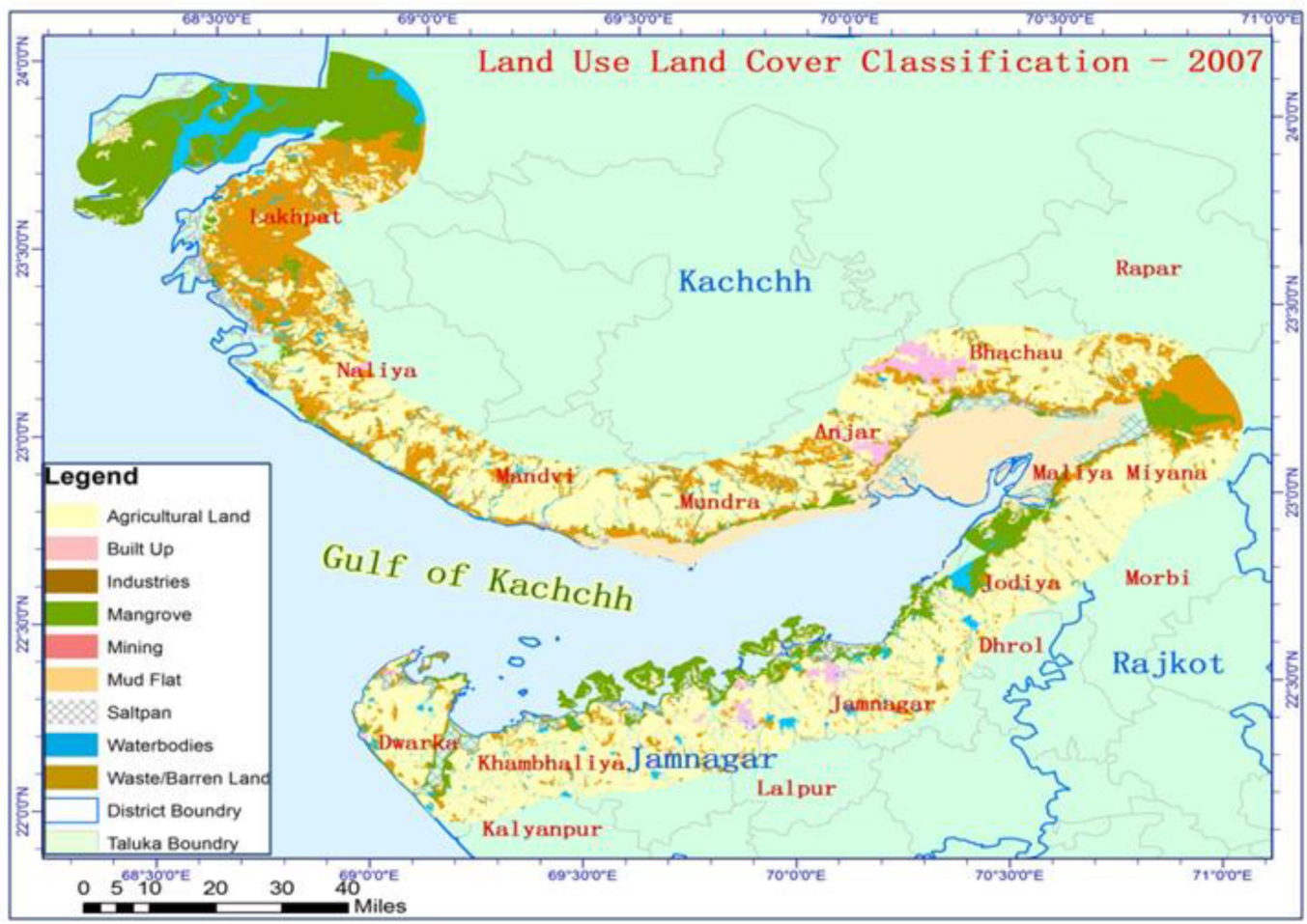

Figure 4: Classified image of the coastal area of GoK in year 2007 


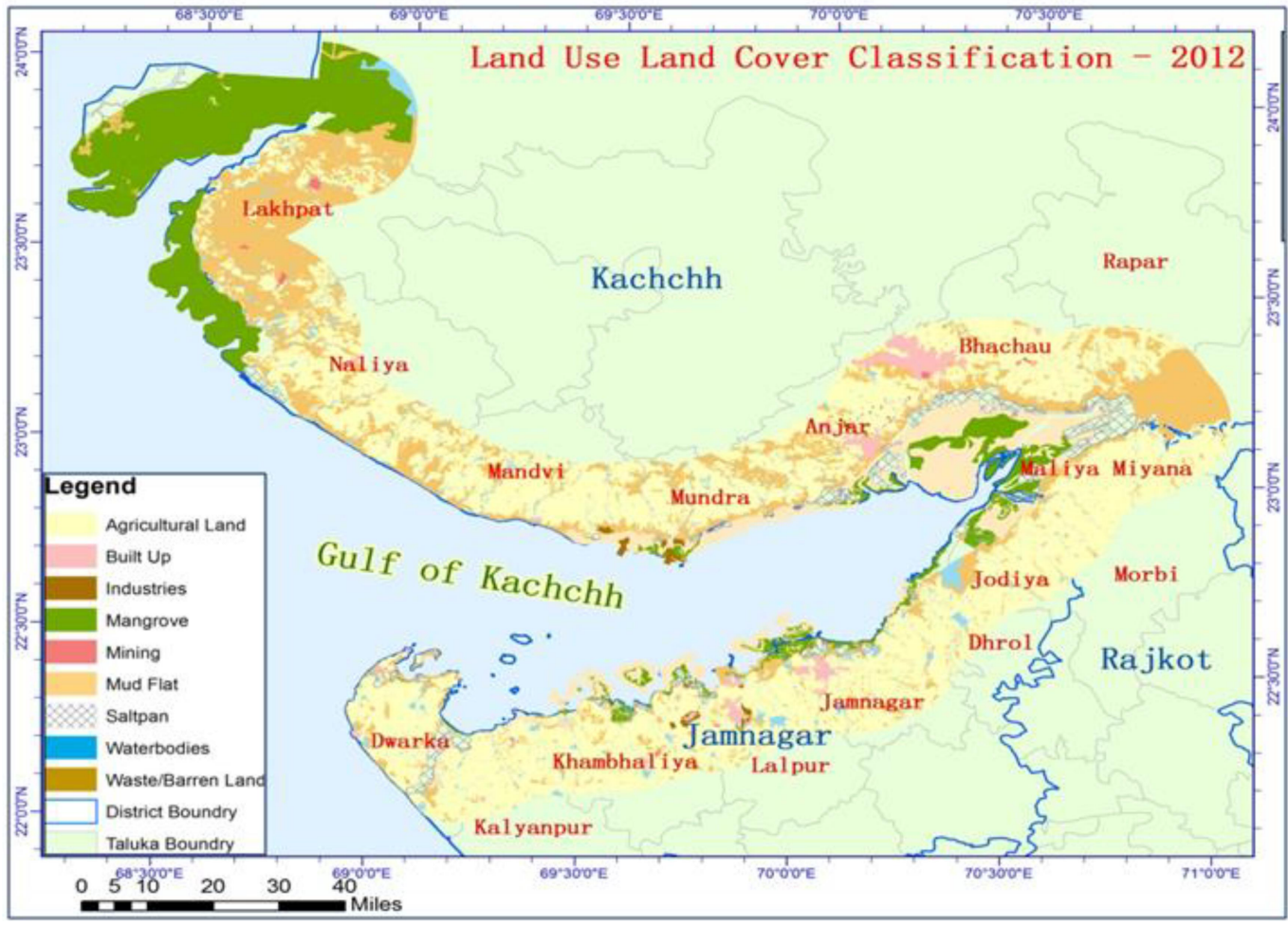

Figure 5: Classified image of the coastal area of GoK in year 2012

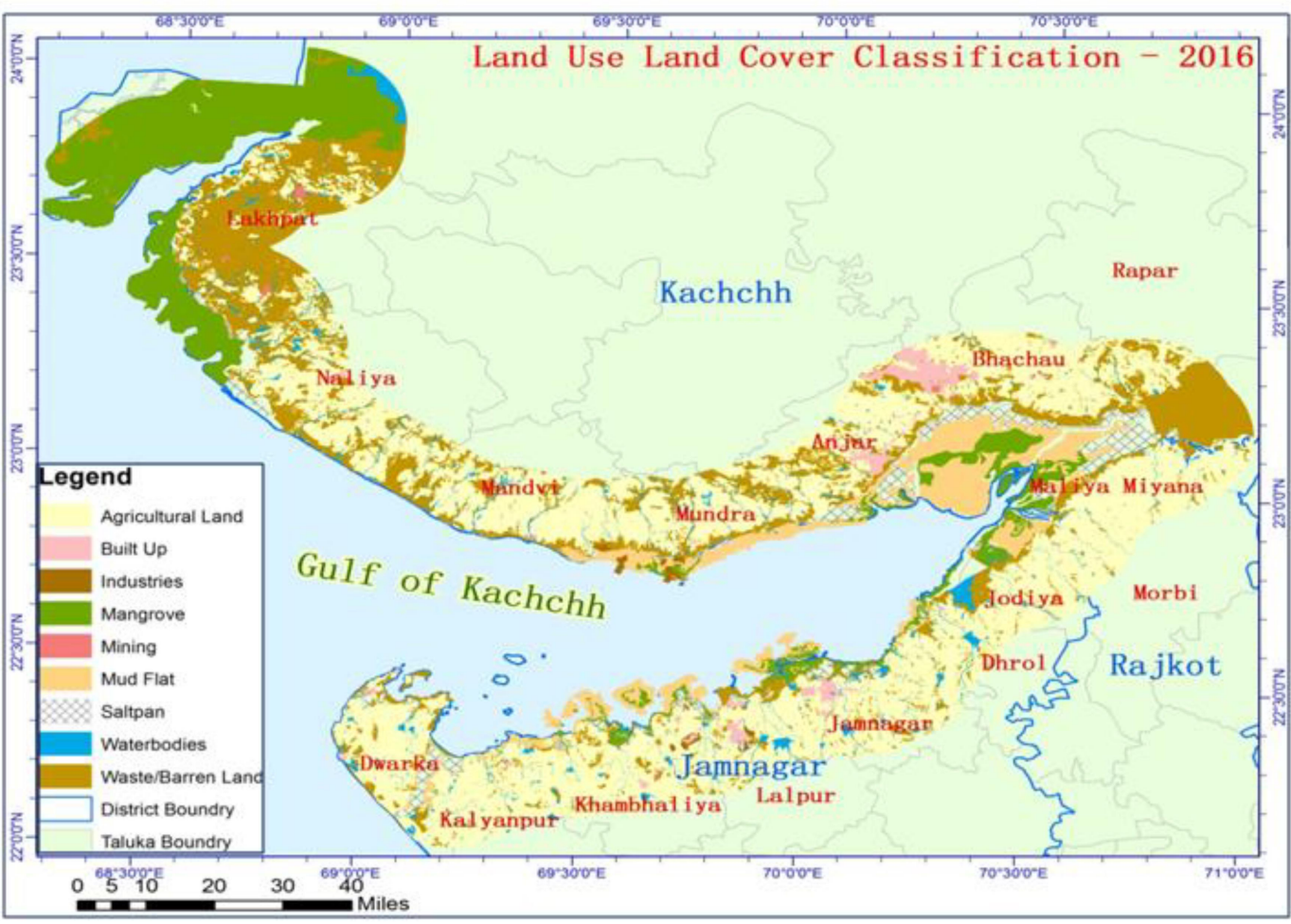

Figure 6: Classified image of the coastal area of GoK in year 2016 
Table 2: Area of each LULC classes in study area

\begin{tabular}{|c|c|c|c|c|c|c|}
\hline Sr. No. & LULC Class & 1997 (ha) & 2002 (ha) & 2007 (ha) & 2012 (ha) & 2016 (ha) \\
\hline 1 & Agricultural Land & $\mathbf{6 8 4 3 2 6}$ & $\mathbf{6 7 5 1 4 3}$ & $\mathbf{6 6 7 1 0 2}$ & $\mathbf{6 5 0 1 6 4}$ & $\mathbf{6 1 8 7 5 3}$ \\
\hline $\mathbf{2}$ & Built Up & $\mathbf{2 3 4 2}$ & $\mathbf{5 6 2 1}$ & $\mathbf{1 8 3 9 1}$ & $\mathbf{3 6 0 2 3}$ & $\mathbf{4 9 1 2 5}$ \\
\hline $\mathbf{3}$ & Industries & $\mathbf{1 9 2 7}$ & $\mathbf{5 0 4 5}$ & $\mathbf{2 0 3 1 3}$ & $\mathbf{3 1 4 6 8}$ & $\mathbf{4 8 3 4 5}$ \\
\hline 4 & Mangrove & $\mathbf{9 5 4 6 5}$ & $\mathbf{8 8 6 7 2}$ & $\mathbf{9 3 8 4 1}$ & $\mathbf{9 6 2 3 6}$ & $\mathbf{9 9 8 2 3}$ \\
\hline $\mathbf{5}$ & Mining & $\mathbf{1 1 2}$ & $\mathbf{3 6 8}$ & $\mathbf{4 6 5}$ & $\mathbf{8 0 8}$ & $\mathbf{9 1 7}$ \\
\hline $\mathbf{6}$ & Mud Flat & $\mathbf{1 7 9 1 0 2}$ & $\mathbf{1 6 7 6 8 0}$ & $\mathbf{1 5 9 8 7 4}$ & $\mathbf{1 4 8 7 5 6}$ & $\mathbf{1 3 6 7 4 8}$ \\
\hline 7 & Salt Pan & $\mathbf{2 9 3 3 4}$ & $\mathbf{5 4 2 9 7}$ & $\mathbf{5 9 4 7 6}$ & $\mathbf{8 0 1 5 2}$ & $\mathbf{1 0 2 5 7 6}$ \\
\hline $\mathbf{8}$ & Water bodies & $\mathbf{8 3 1 7 6}$ & $\mathbf{7 9 5 4 3}$ & $\mathbf{6 2 4 1 6}$ & $\mathbf{4 1 3 2 5}$ & $\mathbf{3 1 5 8 3}$ \\
\hline $\mathbf{9}$ & Waste/Barren Land & $\mathbf{2 8 6 7 2 1}$ & $\mathbf{2 8 6 1 3 6}$ & $\mathbf{2 8 0 6 2 7}$ & $\mathbf{2 7 7 5 7 3}$ & $\mathbf{2 7 4 6 3 5}$ \\
\hline & Total & $\mathbf{1 3 6 2 5 0 5}$ & $\mathbf{1 3 6 2 5 0 5}$ & $\mathbf{1 3 6 2 5 0 5}$ & $\mathbf{1 3 6 2 5 0 5}$ & $\mathbf{1 3 6 2 5 0 5}$ \\
\hline
\end{tabular}

Table 3: Land Use Land Cover (LULC) change

\begin{tabular}{|c|c|c|c|c|c|c|}
\hline $\begin{array}{c}\text { Sr. } \\
\text { No. }\end{array}$ & LULC Class & $\begin{array}{c}\text { Change in ha } \\
1997-2002\end{array}$ & $\begin{array}{c}\text { Change in ha } \\
2002-2007\end{array}$ & $\begin{array}{c}\text { Change in ha } \\
2007-2012\end{array}$ & $\begin{array}{c}\text { Change in ha } \\
2012-2016\end{array}$ & $\begin{array}{c}\text { Change in ha } \\
1997-2016\end{array}$ \\
\hline 1 & Agricultural Land & $\mathbf{- 9 1 8 3}$ & $\mathbf{- 8 0 4 1}$ & $\mathbf{- 1 6 9 3 8}$ & $\mathbf{- 3 1 4 1 1}$ & $\mathbf{- 6 5 5 7 3}$ \\
\hline $\mathbf{2}$ & Built Up & $\mathbf{3 2 7 9}$ & $\mathbf{1 2 7 7 0}$ & $\mathbf{1 7 6 3 2}$ & $\mathbf{1 3 1 0 2}$ & $\mathbf{4 6 7 8 3}$ \\
\hline $\mathbf{3}$ & Industries & $\mathbf{3 1 1 8}$ & $\mathbf{1 5 2 6 8}$ & $\mathbf{1 1 1 5 5}$ & $\mathbf{1 6 8 7 7}$ & $\mathbf{4 6 4 1 8}$ \\
\hline 4 & Mangrove & $\mathbf{- 6 7 9 3}$ & $\mathbf{5 1 6 9}$ & $\mathbf{2 3 9 5}$ & $\mathbf{3 5 8 7}$ & $\mathbf{4 3 5 8}$ \\
\hline $\mathbf{5}$ & Mining & $\mathbf{2 5 6}$ & $\mathbf{9 7}$ & $\mathbf{3 4 3}$ & $\mathbf{1 0 9}$ & $\mathbf{8 0 5}$ \\
\hline $\mathbf{6}$ & Mud Flat & $\mathbf{- 1 1 4 2 2}$ & $\mathbf{- 7 8 0 6}$ & $\mathbf{- 1 1 1 1 8}$ & $\mathbf{- 1 2 0 0 8}$ & $\mathbf{- 4 2 3 5 4}$ \\
\hline $\mathbf{7}$ & Salt Pan & $\mathbf{2 4 9 6 3}$ & $\mathbf{5 1 7 9}$ & $\mathbf{2 0 6 7 6}$ & $\mathbf{2 2 4 2 4}$ & $\mathbf{7 3 2 4 2}$ \\
\hline $\mathbf{8}$ & Water bodies & $\mathbf{- 3 6 3 3}$ & $\mathbf{- 1 7 1 2 7}$ & $\mathbf{- 2 1 0 9 1}$ & $\mathbf{- 9 7 4 2}$ & $\mathbf{- 5 1 5 9 3}$ \\
\hline $\mathbf{9}$ & Waste/Barren Land & $\mathbf{- 5 8 5}$ & $\mathbf{- 5 5 0 9}$ & $\mathbf{- 3 0 5 4}$ & $\mathbf{- 2 9 3 8}$ & $\mathbf{- 1 2 0 8 6}$ \\
\hline
\end{tabular}

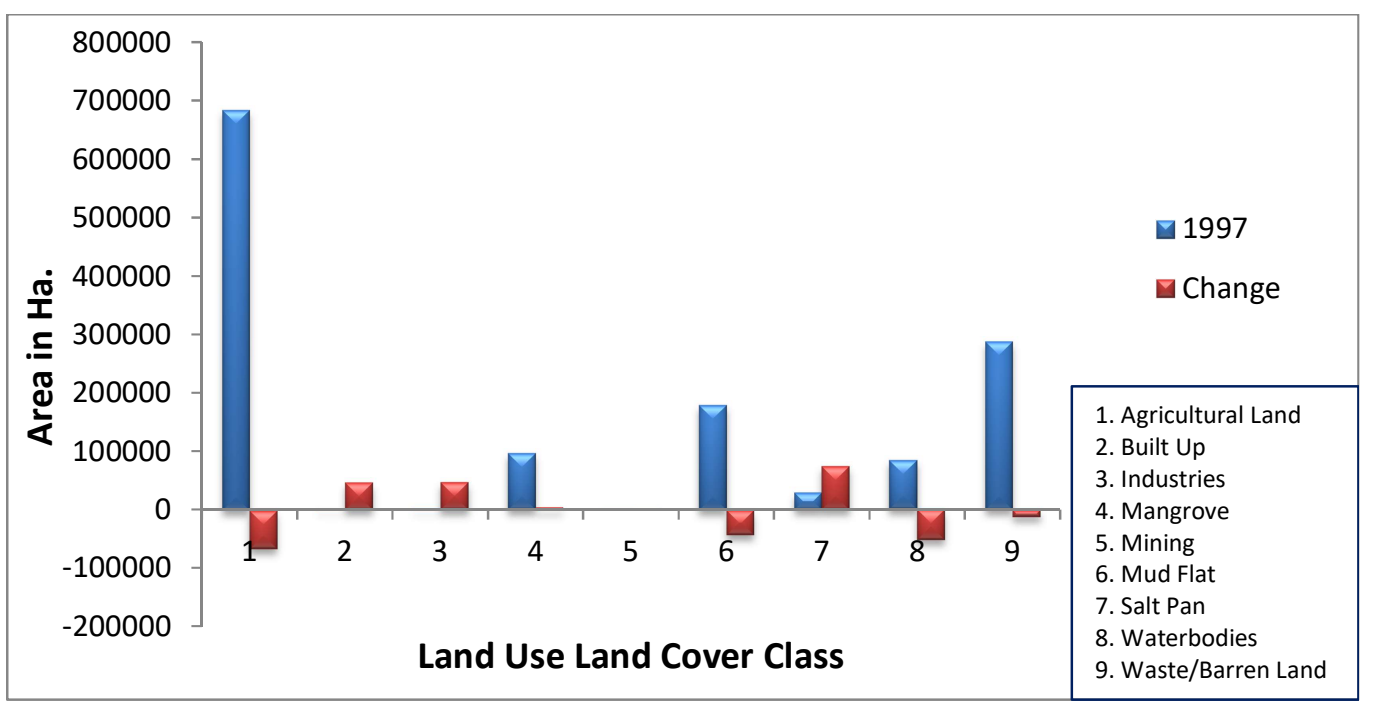

Figure 7: Land Use Land Cover (LULC) change from 1997-2016 in the study area

There are substantial changes observed in the LULC categories from 1997 to 2016. Agricultural land is measured from 684326ha (50.22\%) in 1997 to 618753 ha $(45.41 \%)$ in 2016 indicating the decrease by 65573 ha (4.81\%). Most of the agricultural land found converted into either industries or in built up area might be because of industrialization, urbanization and increase in human population. Several chemical industries, oil refinery and other factories developed near the coastline that reflects the increase in class from $0.14 \%$ in 1997 to $2.38 \%$ in 2016 . Similarly, the built 
up increased from $0.17 \%$ in 1997 to $2.76 \%$ in 2016. Mangroves were observed 95465ha in 1997, which decreased up to 88672ha in 2002 due to the rapid development and expansion of industrial estate. However, after 2002, mangrove area increase as a result of the mangrove plantation by the Government, private NGOs and industries. This also shows that the awareness about the importance of mangrove among the locals as well as in industrialists. In 2016, mangroves observed 99823ha. Due to these efforts and awareness, mangroves cover in the study area is increased by $0.11 \%$. (from $7.00 \%$ in 1997 to $7.11 \%$ in 2016). Increase in mangrove cover has reduce the land covered by the mudflat by $3.11 \%(13.15 \%$ in 1997 to $10.04 \%$ in 2016). Lignite mining increased from 112 ha in 1997 to 917 ha in 2016 at Lakhpat taluka of Kachchh district. Saltpan increased from 29334ha (2.15\%) in 1997 to 102576 ha $(7.52 \%)$ in 2016 . Level of water bodies decreased from $6.10 \%$ to $2.32 \%$ in last twenty years. Waste/barren land was utilized for the mining, built up or industries purpose and hence it is decreased over the period of twenty years (286721ha to $274635 \mathrm{ha}$ ). The results reveal that there is a need to monitor the LULC changes at regular interval which may help to prepare the land use plan for the sustainable development.

\section{CONCLUSION}

This study has given an insight of the change in land cover and land use of coastal zone of Gulf of Kachchh in the past twenty years. This study successfully shows that the major land use land cover change identified in the Gulf of Kachchh is in agricultural land followed by mudflats and water bodies, which are significantly decreased from 1997 to 2016. There are increase in mangrove, saltpan, built up, industries and mining categories in the study area during the 1997 to 2016 . Under utilization of potential land, urbanization, industrialization and increased population are the major driving forces for the change in land use during the past twenty years. The overall accuracy achieved in the study is $91.46 \%$ which is satisfactory and Kappa coefficient is 0.89 which is nearer to one. Digital image processing techniques, change detection procedures coupled with spatial analysis offer valuable tools for scientists, resource managers and policy makers for efficient mapping and monitoring the coastal zone.

\section{ACKNOWLEDGEMENTS}

The authors are thankful to the Utkal University, Bhubaneswar, India for their inspiration to develop this manuscript. First author is thankful to Department of Science and Technology (DST), Government of India for the financial assistance under 
Women Scientist Scheme to carry out this research work. Thanks are also due to the Rashtriya Uchchatar Shiksha Abhiyan (RUSA) scheme of Department of Higher Education, Government of India is duly acknowledged for providing the necessary support to Centre of Environment, Climate Change and Public Health (ECCPH).

\section{REFERENCES}

[1] Yagoub M. M. and Kolan G. R. (2006). Monitoring Coastal Zone Land Use and Land Cover Changes of Abu Dhabi using Remote Sensing. Journal of the Indian Society of Remote Sensing, 34: 57-68.

[2] Nemani R. R. and Running S. W. (1995). Satellite Monitoring of Global Land Cover Changes and their Impact on Climate Change. Climate Change, 31: 395- 413

[3] Anon W. (1992). Agenda 21, United Nations Conference on Environment and Development, Rio de Janeiro, Brazil, June 3-14, 1992. pp. 215-249.

[4] Borges R., Hernandez-Guerra A. and Nykjaer L. (2004). Analysis of sea surface temperature time series of the south-eastern North Atlantic. International J. of Remote Sensing, 25(5): 869-891.

[5] Chakraborty T., Haripriya G. and Vinish K. (2013). Analyzing the Impact of Mundra Port and Special Economic Zone Limited(MPSEZL) on Coastal Environment of Gujarat, India. Seventh Biennial Conference Indian Society for Ecological Economics (INSEE) Global Change, Ecosystems, Sustainability, December 4-8, 2013. pp. 1-21.

[6] Sathyendranath S., Platt T., Horne E., Borstad G., Stuart V., Payzant L., Maass H., Kepkay P., Li W., Spry J. and Gower J. (2004). A Multispectral Remote Sensing Study of Coastal Waters off Vancouver Island. International Journal of Remote Sensing, 25(5): 893-919.

[7] Specter C. and Gayle D. (1990). Managing technology transfer for coastal zone development: Caribbean experts identify major issues. International J. of Remote Sensing, 11(10): 1729-1740.

[8] Prizomwala, S.P., Bhatt, N. and Basavaiah, N. (2014). Provenance discrimination and source-to-sink studies from a dry land fluvial regime: An example from Kachchh, western India. International Journal of Sediment Research, 29(1), 99-109.

[9] Boakye E., Odai N., Adjei A. and Annor O. (2008). Landsat Images for Assessment of the Impact of Land Use and Land Cover Changes on the Barekese Catchment in Ghana. 
European Journal of Scientific

Research, 22(2): 269-278.

[10] Sarma P., Lahkar B., Ghosh S., Rabha A., Das J., Nath N., Dey S. and Brahma N. (2008). Land Use and Land Cover Change and Future Implication Analysis in Manas National Park, India using Multi-Temporal Satellite Data. Current science, 95(2): 1-5.

[11]Lillesand T. and Kiefer R. (2000). Remote Sensing and Image Interpretation. 4th ed. John Wiley and Sons inc. New York.

[12] Abate S. (2011). Evaluating the Land Use and Land Cover Dynamics in Borena Woreda of South Wollo Highlands, Ethiopia. Journal of Sustainable Development in Africa, 13 (1): 87- 105 .

[13] Temesgen G., Amare B. and Abraham M. (2014). Evaluations of Land Use/Land Cover Changes and Land Degradation in Dera District, Ethiopia: GIS and Remote Sensing based analysis. International Journal of Scientific Research in Environmental Sciences, 2(6), 199-208.

[14]Diallo Y., Hu G. and Wen X. (2009). Applications of Remote Sensing in Land Use/Land Cover Change Detection in Puer and Simao Counties, Yunnan Province. Journal of American Science, 5(4): 157-166.
[15] Solaimani K., Arekhi M., Tamartash R. and Miryaghobzadeh M. (2010). Land Use/Cover Change Detection Based on Remote Sensing Data (A Case Study; Neka Basin). Agriculture and Biology Journal of North America, 1(6): 11481157.

[16]Dwivedi L., Sengupta D. and Tripathi S. (2015). Change Detection Mapping of Land Use/ Land Cover Area in Satna District: Using Remote Sensing and GIS Technique. International Journal of Multidisciplinary Research and Development, 2(10): 150-154.

[17] Tiwari K. and Khanduri K. (2011). Land Use / Land Cover Change Detection in Doon Valley (Dehradun Tehsil), Uttarakhand, Using GIS and Remote Sensing Technique. International Journal of Geomatics and Gosciences, 2(1): 34-41. 